$$
\begin{array}{ll}
\text { Research Square } & \begin{array}{l}
\text { Preprints are preliminary reports that have not undergone peer review. } \\
\text { They should not be considered conclusive, used to inform clinical practice, } \\
\text { or referenced by the media as validated information. }
\end{array}
\end{array}
$$

\title{
Green Policy, Corporate Social Responsibility and Environmental Protection Investments - Evidence from Chinese Listed Companies in Heavy Pollution Industries
}

\author{
Jingyi Zhang ( $\square$ zjy0311@126.com) \\ China University of Mining and Technology Beijing Campus
}

\section{Research Article}

Keywords: Green Policy, Corporate Social Responsibility, Corporate Environmental Investment, Market Competition

Posted Date: December 1st, 2021

DOI: https://doi.org/10.21203/rs.3.rs-1054167/v1

License: (a) (1) This work is licensed under a Creative Commons Attribution 4.0 International License. Read Full License 


\section{Abstract}

Corporate environmental investment decision-making behavior is influenced by both the external factor of government green policy and the internal factor of corporate social responsibility. This paper empirically examines the effects of green policies and corporate social responsibility on corporate environmental investment using a fixed-effects panel data model with a sample of Chinese listed companies in the heavy pollution industry from 2013-2019 and further analyzes the possible moderating role played by market competition. The results show that: (1) Green policy and corporate environmental investment have an inverted "U-shaped" relationship, which indicates that there is a "degree" limit to the impact of green policy on corporate environmental investment. (2) There is a U-shaped relationship between green investment and environmental governance green policy tools and corporate environmental investment, while infrastructure green tool and corporate environmental investment in an inverted U-shaped relationship (3) Corporate social responsibility and the scale of its environmental investment has a positive relationship, green policy and corporate social responsibility have a joint effect corporate environmental investment. (4) The higher the degree of market competition, the more significant the effect of green policy on corporate environmental investment.

\section{Introduction}

Over the past 40 years of reform and opening-up, China's economy has increased by leaps and bounds, becoming the world's second-largest economy since 2010. However, rapid economic growth has been built on the high energy consumption, high emissions, high pollution of the crude development method, which led to tightening resource constraints, ecological and environmental degradation of the problem of the date highlighted. According to the latest Environmental Performance Index Report (2020) released by Yale University and Columbia University, China's Environmental Performance Index ranks 120th out of 180 countries, indicating that China's environmental quality is still at the end of the scale from a global perspective, which is in strong contrast to its current status as the world's second-largest economy country. How to reconcile the contradictions and conflicts between economic development and ecological environmental protection has become a major challenge for the government.

More than $80 \%$ of environmental pollutants are produced by enterprises, which have become the main producers of resource consumption and environmental pollution (Shen et al., 2012). As the main contributors to environmental pollution, enterprises have an inescapable responsibility for pollution control and should fulfill their responsibility and invest more in environmental protection. However, due to the negative externalities of environmental pollution, Chinese enterprises generally have the problem of the insufficient scale of green investment (Tang et al., 2013). Corporate pollution control investment is motivated by the need to satisfy legitimacy requirements and is a response to pressure from government environmental policies. In recent years, the Chinese government has also paid more attention to the protection and management of the resource environment and ecological environment, and in the reports of the 18th and 19th CPC National Congress, it has proposed to make efforts to promote green development and circular development, and in conjunction with the introduction of a series of policies and regulations such as Environmental Protection Law of the People's Republic of China. In addition, the Chinese government has continued to promote environmental taxes, emissions trading, and public environmental monitoring systems. Implementation of green policy will inevitably affect the production and operation activities, environmental management, and environmental protection investment behavior of enterprises.

CSR is usually associated as an approach to integrate social and environmental aspects into corporate activities (Baumgartner et al., 2013). Studies have shown that CSR plays a crucial role in determining a company's performance and significantly determines environmental strategy (Kraus S et al., 2020). Based on stakeholder theory, companies face pressure from organizational stakeholders, such as competitors, customers, workers, and governments, who demand that companies talk openly about social and environmental issues (Pekovic and Vogt, 2020), so companies will pay more attention to environmental governance and integrate environmental protection investment into the social responsibility fulfillment process. Does government implementation of green policy promote corporate environmental protection investment? What is the impact of CSR on corporate environmental protection investment? And how do both influence corporate environmental behavior from the perspective of the external policy environment and internal corporate strategy? It is of great theoretical and practical significance to study how government green policy and CSR fulfillment affect corporate environmental protection investment behavior, to enrich and deepen the study of corporate investment theory, optimize corporate investment structure, and reasonably allocate corporate environmental funds.

All aspects of firms' investment decisions, including allocation of funds, choice of technology, and investment in pollution abatement equipment, are influenced by environmental policies (Gray and Shadhegian,1998; Farzin and Kort,2000). Institutional theory suggests that green policy generate regulatory pressure and that firms will not actively participate in environmental protection if the government does not enforce mandatory green policy, and that firms' environmental protection investment is a response when faced with government green policy(Li and Shen,2008; Yuan and Geng,2010). Murovec et al. (2012) point out that the motivation for firms to make environmental protection investment is to meet environmental legality requirements, reduce the expected fines and frequency of regulation by regulators, and ultimately reduce the cost of environmental compliance for firms. The Porter hypothesis also suggests that green policy can lead to "innovation compensation effects" that help to improve environmental performance together with economic performance (Porter, 1991; Porter and Linde,1995). The analysis suggests that firms will expand their environmental protection investment when the intensity of green policy is within their reach, either to meet legitimacy requirements or as a means of "showing goodwill" to the government. However, as the intensity of environmental policies increases, the impact of green policy on firms' environmental protection investment is likely to change. Li and Tao (2012) find that there is an optimal level of green policy intensity. Leiter et al. (2011) find that reasonable green policy intensity can increase firms' environmental protection investment, but their impact diminishes over time. Green policy has a significant negative impact on firm investment when the costs that firms bear to comply with green policy are too high.

Existing research on the impact of corporate social responsibility on corporate environmental protection investment is mainly based on stakeholder theory. The development of enterprises cannot be separated from the participation of all stakeholders and so enterprises should shoulder not only their pecuniary responsibility but also social and environmental responsibility. First, corporate environmental protection investment helps improve corporate environmental

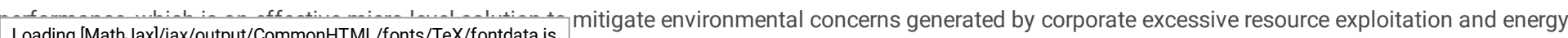


use (Tian et al., 2020). Second, a firm's investment in environmental protection is a competitive strategy. Enhanced investment in environmental protection can reduce the potential cost of environmental discipline and increase the value of the company's products. Active fulfillment of environmental responsibility will increase customer satisfaction, which will lead to a good market reputation for the company (Fuentes-Blasco et al., 2017). Third, by assuming environmental responsibility, enterprises can not only build a good corporate image and demonstrate sound business posture and financial strength (Li and He,2014) but also help to enhance the identification of internal and external stakeholders with the enterprise and create a good external environment for the long-term development of the enterprise.

In summary, although there is a large body of literature surrounding the relationship between green policy and corporate environmental protection investment, no consistent empirical findings have been obtained. Thus, It is necessary to classify green policy into different types so as to further investigate the differences in the impact of different types of green policy tools on corporate environmental investment. Research on corporate environmental protection investment has mainly focused on the role of the external policy environment, but less research has been conducted on the internal mechanisms by which environmental regulation affects corporate behavior, especially from the perspective of social responsibility. So it is necessary to incorporate government green policy and corporate social responsibility into the same framework to study corporate environmental protection investment to reflect the combination of proactive and reactive corporate environmental investment behavior. Due to the substantial differences in policies and regulations, market competition, and cultural environment in different regions of China, there are significant differences in the formulation and implementation of green policy by local governments and in the way companies fulfill their social responsibilities. It is needed to study the regional differences in the effects of green policy and corporate social responsibility on corporate environmental protection investment. The "visible hand" of the government is responsible for designing sound green policy, while the "invisible hand" of the market leads companies to survive and develop under policy regulation and gain competitiveness (Li and Tian,2016). Both the government and the market may have an important influence on the environmental protection investment behavior of firms. It is necessary to introduce the variable of market competition to study the influence of the "two hands" of the government and the market on the environmental protection investment of firms.

The study may contribute to the literature in three ways. First, this paper combines the external policy environment and the intra-company perspective to reveal the relationship between green policy, corporate social responsibility and corporate environmental protection investment. Second, this paper further classifies green policy and conducts a comparative study of the influence of different types of green policy tools on corporate environmental protection investment. The sample was also divided into different regions for comparative studies to further understand the regional differences in the impact of green policy and CSR on corporate environmental investment behavior. Finally, this paper examines the role of market competition in regulating the relationship between green policy and corporate environmental protection investment, analyze the impact on corporate environmental protection investment from the perspective of the "two hands" of government and market, and propose policy recommendations to promote the coordinated development of policy and market mechanisms.

The remaining parts of this paper are organized as follows: Section 2 provides the theoretical analysis and research hypothesis; Section 3 describes the quantitative analysis concerning (a) the sample selection and data sources, (b) the choice of the variables, (c) the econometric models; Section 4 sets out the empirical results and main findings; Section 5 consists of research conclusions and policy recommendations.

\section{Theory And Hypotheses}

\subsection{Green Policy and Corporate Environmental protection investment}

Green policy is a set of policies implemented by national and local governments to guide the transition to a green economy and promote a high degree of integration between economic development and environmental protection to practice the new development concept. In the context of high-quality development, green policy plays a crucial role in facilitating the transformation of social and economic development and indicating the direction of industrial restructuring. Public policy is an important influencing factor in the decision-making behavior and process of enterprises' investment and innovation. On this basis, green policy is an exogenous driving force for enterprises to make pertinent decisions and operations. As a special type of investment for enterprises, environmental protection investment pursues comprehensive benefits including economic, environmental, and social benefits. When making investment decisions, companies need to measure the relative scale of environmental protection investment benefits and environmental protection investment costs. Policy factors such as environmental subsidy standards, environmental treatment intensity, and the level of environmental infrastructure can all have significant and complex effects on corporate environmental protection investment behavior.

Three main theoretical hypotheses exist to explain the impact of green policy on firms' environmental protection investment decision behavior, the Pollution haven hypothesis, the factor endowment hypothesis, and the Porter hypothesis (Tang et al., 2013). The Pollution Heaven hypothesis suggests that polluting firms may move from countries (regions) with stricter environmental policies to countries (regions) with more lenient environmental policies to reduce environmental costs and that strict environmental policies negatively affect firms' environmental protection investment. The factor endowment hypothesis proposes that firms are motivated to invest in environmental protection as long as the resource endowment advantage of environmental regulation is greater than the corresponding cost of environmental compliance. The Porter hypothesis proposes that the development of sound green policy can promote the innovation and application of technology and that corporate investment will further enhance technological innovation, thereby reducing the costs of environmental compliance, maximizing resource utilization, and improving the market competitiveness of firms. These three hypotheses theoretically illustrate the influence of government, an influential external governance agent, on firms' decisions about environmental protection investment behavior. From the perspective of resource allocation, environmental behavior contributes to increasing sustainable economic growth and competitiveness of firms (Despeisse et al., 2012). And the environmental investment behavior of enterprises has the characteristics of high risk, long cycle, and large scale (Hu and Liu, 2021). In general, policies include fiscal incentives, tax measures, regulation, and non-market instruments (Murovec et al., 2012). Green policy is an effective tool for resource allocation, and companies that meet the conditions for green policy support are more likely to receive government financial subsidies in the category

Loading [MathJax]/jax/output/CommonHTML/fonts/TeX/fontdata.js thnology research and development subsidies and clean energy investment subsidies (Huang and 
Yuan,2021). Government funding and subsidies can greatly reduce the risks and costs of corporate environmental protection investment, effectively stimulate corporate environmental protection investment and improve the enthusiasm for corporate environmental protection investment.

Institutional theory suggests that in addition to the goal of maximizing profit, other goals (such as the state and other organizations) can also drive managers' decision-making (Pagell et al., 2013). Enterprises' environmental protection investment is affected by the strength of environmental control. When the binding force and control of green policy are more relaxed, the decision of enterprises to engage in environmental protection investment behavior is more dependent on their actual business conditions and management decisions. Due to the extreme risk, long period, and large scale of environmental protection investment, it is likely that it will not lead to a flow of economic benefits in the future and will be a burden on business performance for a certain period. When the government continues to emphasize the requirements for green development, the binding force, control, and influence of green policy gradually strengthens. Thus, green policy support can provide effective resources for enterprises to make environmental protection investment and promote environmental protection investment behavior to avoid the cost of non-compliance. At this time, the positive incentive effect of policy on corporate environmental protection investment will be more obvious (Huang,2020). In other words, environmental protection investment is a "passive" behavior for enterprises. There is a U-shaped relationship between the intensity of government environmental regulation and firms' environmental protection investment, i.e., there is a "threshold effect" of environmental regulation on firms' environmental protection investment behavior, and firms' environmental protection investment behavior is more characterized as "passive" to meet the needs of government environmental regulation (Tang et al., 2013).

Combining the above three hypotheses and the essential characteristics of corporate environmental protection investment, this paper believes that environmental protection investment, as a special investment behavior of enterprises in linked governance, pursues the unity of environmental and operational benefits: when making investment decisions, enterprises need to comprehensively measure the relationship between environmental protection investment costs and environmental protection investment benefits. Green policy is an institutional arrangement that influences corporate environmental governance behavior, and its relationship with environmental protection investment is not a simple linear relationship, but a curvilinear one. When green policy is at a low level, the lenient green policy can make the amount of environmental protection investment required by companies higher than environmental taxes and environmental fines, so companies are less motivated to spend on environmental protection. With lower green policy intensity, green policy is negatively correlated with corporate environmental protection investment. When the green policy is improved to a certain extent, the environmental taxes and environmental fines paid by enterprises exceed the environmental protection investment, then enterprises have to pay attention to their environmental pollution control and environmental protection investment to maintain a higher degree of compliance with green policy, that is, there is a positive correlation between the level of green policy and the scale of corporate environmental protection investment at this time. Based on the above analysis, this paper proposes the following hypotheses:

\section{Hypothesis 1}

There is a U-shaped relationship between green policy and corporate environmental protection investment.

\subsection{Corporate Social Responsibility and Corporate Environmental protection investment}

Corporate social responsibility is a business model, behavior, and value orientation of a company as a "corporate citizen", emphasizing the need for companies to develop sustainably. Corporate social responsibility is usually associated with an approach to integrating social and environmental aspects into corporate activities (Baumgartner, 2013). The academic community has shown that corporate social responsibility orientation is essential for stimulating longterm stability, growth, and sustainable performance in a dynamic and changing environment (Luo and Homburg, 2007; Gyves and O’Higgins, 2008).

Corporate investment in environmental protection is first and foremost a competitive strategy, part of corporate governance, and a reflection of social responsibility. Corporate environmental protection investment helps improve corporate environmental performance, which is an effective micro-level solution to mitigate environmental concerns generated by corporate excessive resource exploitation and energy use (Tian et al., 2020). Fulfilling environmental responsibility can not only reduce the potential cost of environmental punishment, increase the value of the company's products, but also help the company achieve long-term sustainable development. Lao (2013) found that with the economic development of China and the continuous improvement of the overall education level of the nation, the market for environmentally friendly products has become increasingly broad. Based on the market profit motive, although increasing corporate environmental protection investment will increase certain operating costs, companies can attract more consumers who favor the brand concept of "green economy" and "low-carbon life" through green innovation(Mark and SusanWatts,2013) which will further enhance its unique competitive advantage and reduce the external business pressure brought by the fierce competition in the industry. Enterprises that fulfill their environmental responsibility in the short term will generate a certain amount of environmental capital investment. However, in the long run, it will enhance consumer recognition, improve product value and ultimately increase company value.

Based on signaling and stakeholder theory, by undertaking social responsibility, companies can establish positive interactions with stakeholders, build a positive corporate image and reputation, send a signal to the outside world for continuous high-quality development, and bring convenience in financing (Liu and Wang, 2012). By assuming environmental responsibility, companies can build a good corporate image and demonstrate sound business posture and financial strength (Li and He,2014). Moreover, as a series of contracts combination among stakeholders such as owners of physical capital, owners of human capital, and creditors, enterprises can create a favorable external environment for their long-term development by purposefully and systematically assuming responsibilities to various stakeholders under market economic conditions, which is conducive to maintaining the interests of various stakeholders and enhancing the identification of internal and external stakeholders with the enterprise(Zhang et al.,2009). This increases the possibility of maintaining longterm stable cooperation with customers, suppliers, and other stakeholders, obtaining sustainable competitive advantages, and further improving corporate environmental performance. In order to build a good image, increase profitability and win social influence, companies tend to fulfill their social responsibility, increase environmental protection investment and take positive environmental protection investment behavior, which will also promote the positive Loading [MathJax]/jax/output/CommonHTML/fonts/TeX/fontdata.js 
relationship between corporate social responsibility and environmental protection investment. To a certain extent, corporate social responsibility enhances the motivation of enterprises to make environmental protection investment. This paper proposes the following hypothesis:

\section{Hypothesis 2}

Corporate social responsibility can positively promote corporate investment in environmental protection.

\subsection{Green Policy, Corporate Social Responsibility, and Corporate Environmental protection investment}

From a governance perspective, green policy as an external governance factor and corporate social responsibility as an internal governance factor generate exogenous impetus on corporate investment behavior under the policy environment and endogenous motivation under corporate governance, respectively (Ren, 2017). Therefore, this paper proposes the following hypothesis to better investigate the relationship between green policy, corporate social responsibility, and corporate environmental protection investment. This paper proposes the following hypothesis:

\section{Hypothesis 3}

Green policy and corporate social responsibility can work together on corporate environmental protection investment.

\subsection{The moderating effect of market competition}

The concentration and fragmentation of the industry determine the state of competition at the industry level and influences firms' business behavior by affecting their distribution of resources and information as well as their choice of risk strategies. In China, the heavy pollution industry is characterized by low barriers to entry and high-intensity competition, which exposes firms to a high level of threat from new entrants and existing competitors in the industry (Fu and Wang,2018). To maintain an advantage in fierce market competition, enterprises' competitive strategies must be more diversified, and gaining a competitive advantage by increasing investment in environmental protection is increasingly becoming an important development strategy for heavy polluters. Studies generally agree that market competition has a moderating effect on corporate environmental protection investment (Luken and Rompaey, 2008; Chaton and Guillerminet,2013). According to Porter's theory of competitive advantage, companies gain competitive advantage mainly by cost leadership and product differentiation. The pressure of regulation, standardization, and cognitive imitation brought by green policy is equivalent to setting entry barriers in the industry and eliminating enterprises that are not environmentally friendly from the market. The surviving firms achieve product differentiation and customer recognition by mastering green technologies, and environmental technology innovations help reduce production costs and contribute to productivity improvements and profit increases. (Sun et al.,2012; Jiang and Tian,2014).

Rent-seeking theory, on the other hand, provides a research perspective on the synergy between government and business. When external market competition is more intense, companies will develop a stronger willingness to seek political rents, and then will enhance environmental protection investment to obtain government resource support, to obtain a certain degree of government assistance in tax burden, market access, and financing (Li et al,2015). Therefore, companies within highly competitive industries are more positive about green policy introduced by the government and use environmental protection investment as a way to obtain support from government resources, so the implementation of green policy is more effective. Based on the above analysis, this paper proposes the following hypothesis.

\section{Hypothesis 4}

Market competition can positively moderate the relationship between green policy and corporate environmental protection investment.

\section{Methods}

\subsection{Data source and processing}

The study sample consisted of Chinese A-shares listed companies in the heavy pollution industry that disclose the amount of corporate investment in environmental protection from 2013 to 2019 (China Securities Regulatory Commission industry classification codes B, C0, C1, C2, C3, C4, C6, C8, and D). The sample companies were

processed as per the following rules: (1) Samples of special treatment (ST, *ST, SST) listed companies were excluded. (2) Sample companies with gearing ratios greater than 1 and net return on total assets less than 0 were excluded. (3) Sample companies with missing values in variables were excluded. This led to a final sample of 287 companies in the heavy pollution industry.

The corporate green investment data were collected manually from the corporate social responsibility (CSR) report, sustainability report, and environmental report, including investment in environmental protection technology improvement projects, pollution treatment investment, environmental protection facility renovation, operation and management, sewage fee payment, clean production, and other inputs. The data of green policy were obtained from China Green Development Index Report . The data of corporate social responsibility came from Hexun.com Corporate Social Responsibility Score of Listed Companies. The data of other research variables in this paper were obtained from the China Stock Market and Accounting Research (CSMAR) database. To avoid interference caused by extreme outliers, all continuous variables were winsorized on the $1 \%$ and $99 \%$ quantile.

\subsection{Variable description}




\subsubsection{Dependent variable}

Environmental protection investment (EPI). In this paper, this paper referred to the study of Tang et al. (2013) and used the ratio of the amount of environmental protection investment to the average total assets of enterprises as a proxy for corporate environmental protection investment

\subsubsection{Core variables}

Green policy(Policy). This paper used the level of government policy support for green development in each region from China Green Development Index Report as a proxy variable for green policy. China Green Development Index Report constructs a green development index system for provinces, regions, and cities, and comprehensively measures the extent of government policy support for green development based on three aspects: green investment,

infrastructure, and environmental governance.

Corporate social responsibility(CSR). This paper adopted the scores on CSR of listed companies by Hexun.com, a third-party organization, as a proxy variable for CSR. Hexun.com has constructed a comprehensive scoring system for indicators of shareholders' responsibility, employees' responsibility, suppliers', customers' and consumers' rights and interests' responsibility, environmental responsibility, and social responsibility of listed companies. To avoid the effect of extreme differences, this paper referred to the study of Zhou et al. (2020) and divided the CSR score by 100.

\subsubsection{Moderating variable}

Market competition(MC). In this paper, the Herfindahl-Hirschman Index of sales revenue was used to measure the degree of market competition in the industry, based on the research method commonly used by Yi et al. (2010). The Herfindahl-Hirschman Index was calculated by calculating the market share of each firm in the industry and then summing the squares of the market shares of each firm in the industry. To facilitate the analysis, the inverse of the HerfindahlHirschman Index was used as a proxy variable for market competition.

\subsubsection{Control variables}

Based on the pre-existing literature, this paper selected the control variables which affect the environmental protection investment of the enterprise, of the enterprise characteristics, investment opportunities, asset size, accounting income, financial status, and corporate governance, etc. The specific control variables were selected as follows:(1) Investment opportunity (Opportunity), expressed as the ratio of total market capitalization to replacement cost of assets. (2) Enterprise size (Size), expressed as a natural logarithm of the average total assets of the firms. (3) Enterprise age (Age), expressed as the difference between the year of observation minus the year of company registration. (4) Financial leverage (Lev), expressed as the ratio of total liabilities to total assets.

(5) Firm performance (ROA), expressed as the rate of return on average corporate assets. (6) Operating income growth ratio (Growth), expressed as the ratio of the amount of change in current year operating income to prior year operating income. (7) Fixed asset ratio (Far), expressed as the ratio of fixed assets to total assets. (8) Cash flow adequacy (Flow), expressed as a ratio of net cash flows from operating activities to total assets. (9) Cash holdings (Cash), expressed as the ratio of ending monetary funds to average total assets. (10) Equity concentration (Top), expressed as the percentage of shares held by the top shareholder. (11) Year fixed effect (Year). Set the annual dummy variable according to the sample from 2013 to 2019.

\subsection{Model}

Based on the previous theoretical analysis, to test the separate and joint impacts of green policy and corporate social responsibility on corporate environmental protection investment, as well as the moderating effect of market competition, the following baseline regression models were established:

Model 1: The model of the impact of green policy on corporate environmental protection investment.

$$
\begin{gathered}
\text { EPI }_{i, t}=\alpha_{0}+\alpha_{1} \text { Policy }_{i, t-1}+\alpha_{2} \text { Policy }_{i, t-1}+\alpha_{3} \text { Opportunity }_{i, t}+\alpha_{4} \text { Size }_{i, t} \\
+\alpha_{5} \text { Age }_{i, t}+\alpha_{6} \text { Lev }_{i, t}+\alpha_{7} \text { ROA }_{i, t}+\alpha_{8} \text { Growt }_{i, t}+\alpha_{9} \text { Far }_{i, t}+\alpha_{10} \text { Flow }_{i, t} \\
+\alpha_{11} \text { Cas }_{i, t}+\alpha_{12} \text { Top }_{i, t}+\text { year } \\
+\varepsilon_{i, t}
\end{gathered}
$$

Model 2: The model of the impact of corporate social responsibility on corporate environmental protection investment.

$$
\begin{gathered}
\text { EPI }_{i, t}=\alpha_{0}+\alpha_{1} \text { Policy }_{i, t-1}+\alpha_{2} \text { Policy }_{i, t-1}+\alpha_{3} \text { Opportunity }_{i, t}+\alpha_{4} \text { Size }_{i, t} \\
+\alpha_{5} \text { Age }_{i, t}+\alpha_{6} \text { Lev }_{i, t}+\alpha_{7} \text { ROA }_{i, t}+\alpha_{8} \text { Growt }_{i, t}+\alpha_{9} \text { Far }_{i, t}+\alpha_{10} \text { Flow }_{i, t} \\
+\alpha_{11} \text { Cash }_{i, t}+\alpha_{12} \text { Top }_{i, t}+\text { year }+\varepsilon_{i, t}
\end{gathered}
$$

Model 3: The model of the joint effect of green policy and corporate social responsibility on corporate environmental protection investment.

$$
\begin{gathered}
\text { EPI }_{i, t}=\gamma_{0}+\gamma_{1} \text { Policy }_{i, t-1}^{2}+\gamma_{2} \text { Policy }_{i, t-1}+\gamma_{3} \text { CSR }_{i, t}+\gamma_{4} \text { Opportunity }_{i, t} \\
+\gamma_{5} \text { Size }_{i, t}+\gamma_{6} \text { Age }_{i, t}+\gamma_{7} \text { Lev }_{i, t}+\gamma_{8} \text { ROA }_{i, t}+\gamma_{9} \text { Growt }_{i, t}+\gamma_{10} \text { Far }_{i, t} \\
+\gamma_{11} \text { Flow }_{i, t}+\gamma_{12} \text { Cas }_{i, t}+\gamma_{13} \text { Top }_{i, t}+\text { year }+\varepsilon_{i, t}
\end{gathered}
$$


Model 4: The model of the moderating effect of market competition on the relationship between green policy and corporate environmental protection investment.

$$
\begin{gathered}
\text { EPI }_{i, t}=\alpha_{0}+\alpha_{1} \text { Policy }_{i, t-1}+\alpha_{2} \text { Policy }_{i, t-1}^{2}+\alpha_{3} \text { Policy }_{i, t-1} \times M C_{i, t} \\
+\alpha_{4} \text { Policy }^{2}{ }_{i, t-1} \times M C_{i, t}++\alpha_{5} M C_{i, t}+\alpha_{6} \text { Opportunity }_{i, t}+\alpha_{7} \text { Size }_{i, t} \\
+\alpha_{8} \text { Age }_{i, t}+\alpha_{9} \text { Lev }_{i, t}+\alpha_{10} \text { ROA }_{i, t}+\alpha_{11} \text { Growt }_{i, t}+\alpha_{12} \text { Far }_{i, t} \\
+\alpha_{13} \text { Flow }_{i, t}+\alpha_{14} \text { Cash }_{i, t}+\alpha_{15} \text { Top }_{i, t}+\text { year }+\varepsilon_{i, t}
\end{gathered}
$$

Considering the influence of green policy on corporate environmental protection investment is hysteretic and a possible causal relationship between them, I lagged the green policy variable by one period to reduce endogeneity. Considering the macro impact of different years, this paper also introduced the time dummy variable Year.

\section{Empirical Results}

\subsection{Descriptive statistics and correlation analysis}

This paper used descriptive statistics and correlation analysis for continuous variables. The descriptive statistics for the variables are shown in Table 1. Among the 1640 samples selected, the mean value of the amount of corporate environmental protection investment as a percentage of average total assets $(E P I)$ is 0.002 , the minimum value is close to 0 , and the maximum value is 0.02 , indicating that the scale of environmental protection investment in listed companies in the heavy pollution industry from 2013-2019 is small and uneven among enterprises. The minimum value of corporate social responsibility (CSR) is 0.088 , the maximum value is 0.743 , and the mean value is 0.255 , which indicates that there are significant differences in the performance of corporate social responsibility among enterprises.

Table 1

Descriptive statistic

\begin{tabular}{|llllll|}
\hline Variable & Obs & Mean & Std. Dev & Min & Max \\
\hline EPI & 1640 & 0.002 & 0.003 & 0.000 & 0.021 \\
\hline Policy & 1640 & 0.185 & 0.027 & 0.145 & 0.221 \\
\hline CSR & 1640 & 0.255 & 0.133 & 0.088 & 0.743 \\
\hline Opportunity & 1640 & 1.762 & 0.847 & 0.852 & 5.307 \\
\hline Size & 1640 & 22.389 & 1.408 & 20.087 & 26.471 \\
\hline Age & 1640 & 16.503 & 5.117 & 5.000 & 28.000 \\
\hline Lev & 1640 & 0.385 & 0.171 & 0.074 & 0.754 \\
\hline ROA & 1640 & 0.057 & 0.040 & 0.003 & 0.212 \\
\hline Growth & 1640 & 0.136 & 0.260 & -0.288 & 1.480 \\
\hline Far & 1640 & 0.302 & 0.153 & 0.049 & 0.749 \\
\hline Flow & 1640 & 0.073 & 0.060 & -0.082 & 0.248 \\
\hline Cash & 1640 & 0.157 & 0.110 & 0.018 & 0.572 \\
\hline Top & 1640 & 0.366 & 0.144 & 0.097 & 0.750 \\
\hline MC & 1623 & 22.308 & 16.697 & 1.993 & 49.572 \\
\hline
\end{tabular}

This paper used Pearson correlation analysis to assess associations between variables. In model 1 and model 3 , since the explanatory variables contain a quadratic term Policy ${ }^{2}$, to improve the reliability of the research results, Policy ${ }^{2}$ was centralized in this paper. The variance inflation factor is used to determine whether there is a multicollinearity problem, and the results show that the variance inflation factor VIF of all variables is less than 3 , indicating that there is no serious multicollinearity problem. In model 2 , the correlation coefficients between explanatory variables and control variables in the model are less than 0.5 , and the variance inflation factors VIF between variables in the regression analysis are also less than 2, indicating that the variables are selected reasonably and there is no serious multicollinearity problem between variables.

\subsection{Baseline regression}

For hypothesis 1, the green policy variables were centralized in this paper to reduce the cointegration problem brought by the introduction of the green policy squared term in the model. This paper assessed potential autocorrelation using the Durbin-Watson statistic, and the test results indicated that the models did not indicate severe serial correlation. This paper used the White test and the Breush-Pagan test to find models show significant heteroscedasticity, therefore, 
this paper used a robust standard error method to eliminate the effect of heteroskedasticity. The main results of the baseline regression are represented in Table 2.

As shown in Table 2, in Model 1, the regression coefficient of green policy is significantly negative and passes the significance test at the $1 \%$ level, which indicates that the increase in the level of green policy hinders the growth of corporate environmental protection investment. However, the regression coefficient of the squared term of green policy is significantly positive at the $1 \%$ level, indicating that a higher level of green policy has a promotional effect on corporate environmental protection investment, indicating that there is a significant U-shaped relationship between the level of green policy and corporate environmental protection investment and that there is a "threshold effect" of green policy on corporate environmental protection investment behavior. Lower levels of green policy negatively affect firms' environmental behavior, and firms will neglect environmental protection investment at the cost of lower environmental taxes and environmental fines. However, when the level of green policy exceeds a certain limit, the cost of environmental damage to enterprises rises rapidly and is greater than the cost of environmental protection investment, and as the binding force, control, and influence of green policy gradually strengthens, green policy support can provide effective resources for enterprises to make environmental protection investment, whether to meet the legality requirements or to obtain the innovative compensation effect, enterprises will adopt a responsive and catering attitude to green policy. Therefore, the improvement of the level of green policy plays a positive role in the environmental protection investment behavior of enterprises. Green policy has a dual effect on corporate environmental protection investment, and whether green policy can promote corporate environmental protection investment depends on the trade-off between the costs and benefits of corporate environmental protection investment.

In model 2, the regression coefficient of corporate social responsibility is significantly positive at the $5 \%$ level, and hypothesis 2 of this study is supported. It is an inevitable choice for companies to enhance their investment in environmental protection when fulfilling their social responsibility. By embedding social responsibility fulfillment into environmental protection investment practices, companies can not only reduce potential environmental disciplinary costs and increase the value of the company's products, but also help companies to establish a good corporate image, enhance the trust of investors and consumers, and gain sustainable competitive advantages in market competition. In model 3 , the regression coefficient of the quadratic term of green policy is significantly positive at the $1 \%$ level, and the regression coefficient of corporate social responsibility is significantly positive at the $5 \%$ level, which indicates that the combined effect of external green policy and internal corporate social responsibility affects corporate environmental protection investment. The lenient green policy will not increase the scale of corporate investment in environmental protection, but when the green policy is improved to a certain extent, it will work together with corporate social responsibility to increase the scale of corporate environmental protection investment. 
Table 2

The results of full-sample regression

\begin{tabular}{|c|c|c|c|c|c|}
\hline & (1) & (2) & (3) & (4) & (5) \\
\hline & & & & IV-GMM & IV-GMM \\
\hline & EPI & EPI & EPI & EPI & EPI \\
\hline \multirow[t]{2}{*}{ Policy } & $0.788068^{\star \star \star}$ & & $0.778970 * \star \star$ & $-0.187066^{\star \star \star}$ & $-0.192048^{\star \star \star}$ \\
\hline & $(5.181)$ & & $(5.161)$ & $(-2.631)$ & $(-2.677)$ \\
\hline \multirow[t]{2}{*}{ Policy ${ }^{2}$} & $15.353038 * \star \star$ & & $15.217664^{\star \star \star}$ & $0.495746^{\star \star}$ & $0.506425^{\star \star \star}$ \\
\hline & (4.638) & & $(4.625)$ & $(2.554)$ & $(2.584)$ \\
\hline \multirow[t]{2}{*}{ CSR } & & $0.000976^{\star \star}$ & $0.000976^{\star \star}$ & & 0.000778 ** \\
\hline & & $(2.323)$ & $(2.323)$ & & (1.085) \\
\hline \multirow[t]{2}{*}{ Opportunity } & 0.000107 & 0.000117 & 0.000117 & $-0.000333^{\star}$ & $-0.000333^{*}$ \\
\hline & $(0.747)$ & $(0.823)$ & $(0.823)$ & $(-1.690)$ & $(-1.663)$ \\
\hline \multirow[t]{2}{*}{ Size } & -0.000045 & -0.000093 & -0.000093 & $-0.000348^{\star \star \star}$ & $-0.000365^{\star \star \star}$ \\
\hline & $(-0.130)$ & $(-0.265)$ & $(-0.265)$ & $(-2.950)$ & $(-3.093)$ \\
\hline \multirow[t]{2}{*}{ Lev } & 0.000291 & 0.000231 & 0.000231 & $-0.001676^{\star}$ & $-0.001688^{\star}$ \\
\hline & $(0.336)$ & $(0.266)$ & $(0.266)$ & $(-1.672)$ & $(-1.671)$ \\
\hline \multirow[t]{2}{*}{ Age } & $0.000548^{\star \star}$ & 0.000564 ** & $0.000564 * \star$ & 0.000001 & 0.000000 \\
\hline & $(2.214)$ & $(2.295)$ & $(2.295)$ & $(0.055)$ & $(0.021)$ \\
\hline \multirow[t]{2}{*}{ ROA } & $0.004917^{*}$ & 0.004124 & 0.004124 & $0.009948^{\star \star}$ & $0.009693^{*}$ \\
\hline & $(1.722)$ & $(1.480)$ & $(1.480)$ & (1.986) & (1.912) \\
\hline \multirow[t]{2}{*}{ Growth } & 0.000036 & 0.000046 & 0.000046 & -0.000009 & -0.000009 \\
\hline & $(0.177)$ & $(0.229)$ & $(0.229)$ & $(-0.235)$ & $(-0.243)$ \\
\hline \multirow[t]{2}{*}{ Far } & $0.002301^{*}$ & $0.002325^{\star}$ & $0.002325^{\star}$ & $0.001786^{\star}$ & $0.001874^{*}$ \\
\hline & (1.916) & $(1.931)$ & $(1.931)$ & $(1.726)$ & $(1.800)$ \\
\hline \multirow[t]{2}{*}{ Flow } & -0.001191 & -0.001274 & -0.001274 & -0.000329 & -0.000488 \\
\hline & $(-1.216)$ & $(-1.309)$ & $(-1.309)$ & $(-0.115)$ & $(-0.171)$ \\
\hline \multirow[t]{2}{*}{ Cash } & 0.000841 & 0.000846 & 0.000846 & 0.000843 & 0.000889 \\
\hline & $(0.686)$ & $(0.691)$ & $(0.691)$ & $(0.576)$ & $(0.603)$ \\
\hline \multirow[t]{2}{*}{ Top } & -0.002040 & -0.002117 & -0.002117 & $0.001842^{\star \star}$ & $0.001851^{\star *}$ \\
\hline & $(-1.267)$ & $(-1.330)$ & $(-1.330)$ & $(2.020)$ & $(2.002)$ \\
\hline \multirow[t]{2}{*}{ _cons } & -0.000765 & -0.005087 & -0.000273 & $0.026145^{\star \star \star}$ & $0.026896^{\star \star *}$ \\
\hline & $(-0.092)$ & $(-0.615)$ & $(-0.033)$ & $(3.360)$ & $(3.430)$ \\
\hline Year & Control & Control & Control & & \\
\hline $\mathrm{N}$ & 883 & 878 & 878 & 883 & 878 \\
\hline $\mathrm{F}$ & 3.551 & 3.291 & 3.291 & 2.34 & 2.32 \\
\hline $\mathrm{R}^{2}$ & 0.145 & 0.149 & 0.149 & 0.133 & 0.146 \\
\hline Kleibergen-Paap rk LM statistic) & & & & 314.759 *** & $320.308 * * *$ \\
\hline Kleibergen-Paap rk Wald F statistic & & & & 19000 & 20000 \\
\hline Note: $(1) * \star \star ~ p<0.01, * \star p<0.05, * p<0$ & (2) Figures in & arentheses a & standard errors & & \\
\hline
\end{tabular}

\subsection{Endogeneity of green policy}

The baseline regression results show that there is a robust and significant U-shaped relationship between green policy and corporate environmental protection investment. Although this paper have lagged the green policy variables for one period, the endogenous problem may still exist. To overcome it, this paper Loading [MathJax]/jax/output/CommonHTML/fonts/TeX/fontdata.js nent estimation method (IV-GMM) to conduct empirical tests for green policy and corporate 
environmental protection investment and tested whether the instrumental variables were weak instrumental variables with Kleibergen-Paap rk Wald Fstatistics, and Kleibergen-Paap rk LM-statistics to test the under-identification of instrumental variables respectively. The results show that the KleibergenPaap rk Wald $\mathrm{F}$ statistic exceeds the critical value, testing that there is no problem with weak instrumental variables. The Kleibergen-Paap rk LM statistic is significant at the $1 \%$ level, indicating that the under-identification hypothesis should be rejected. The results of the above tests indicate that the instrumental variables selected in this paper are valid. The regression results using the panel instrumental variable method are shown in columns 4 and 5 of Table 2.

In model 1, the regression coefficient of green policy is significantly negative and the coefficient of its squared term is significantly positive, indicating a significant and robust U-shaped relationship between green policy and corporate environmental protection investment. Hypothesis 1 in this paper is verified. In model 3, the U-shaped relationship between green policy and corporate environmental protection investment still exists. The regression coefficient of CSR is significantly positive at the $5 \%$ level, indicating that CSR has a positive impact on corporate environmental protection investment. When green policy is improved to a certain extent, green policy will have a joint promotion effect with corporate social responsibility on corporate environmental protection investment. Hypothesis 3 in this paper is verified.

\subsection{Further research}

\subsubsection{Impact of different green policy types on environmental protection investment}

This paper divided green policy tools into three types to further analyze the different impacts that different types of green policy tools may have on corporate environmental protection investment. Due to the lack of data, this paper used data from 2016-2019 for analysis. Based on China Green Development Index Report, this paper split the green policy index into green investment index, infrastructure index, and environmental governance index. The green investment index includes five indicators: the proportion of government expenditure on environmental protection to fiscal expenditure, the proportion of investment in environmental pollution control to regional GDP, the government investment in toilet conversion per capita in rural areas, the completion of investment in reforestation per unit of arable land area, and the proportion of expenditure on science, education, culture and health to fiscal expenditure, which comprehensively reflect the financial investment of local governments to solve environmental problems. The infrastructure index includes nine indicators: urban green area per capita, urban water penetration rate, urban wastewater treatment rate, urban household garbage harmless treatment rate, urban public vehicles per 10,000 people, urban public transportation operating route network length per capita, the proportion of rural population benefiting from water reform in rural areas, Internet broadband access ports per capita and the amount of greening coverage in built-up areas, which comprehensively reflect the level of local government's construction of green infrastructure. The environmental governance index includes six indicators: new forestation area per capita for the year, industrial sulfur dioxide removal rate, industrial wastewater chemical oxygen demand removal rate, industrial nitrogen oxide removal rate, industrial wastewater ammonia nitrogen removal rate, and the number of environmental emergencies, which comprehensively reflect the intensity of environmental controls imposed on the company by local government regulators.

This paper analyzed the impact of three types of green policy on corporate green investment behavior, and the regression results are shown in Table 3 . The regression coefficient of the quadratic term of green investment is significantly positive at the $1 \%$ level, indicating that there is a significant U-shaped relationship between government green investment and corporate environmental protection investment. Increased government spending on environmental protection will promote increased demand for production factors by firms, while the constant supply of production factors in the short term will lead to higher prices, increasing the cost of environmental protection investment by firms, who will shift their funds to other areas to maximize profits. There is a substitution effect of government environmental protection spending on enterprise environmental protection investment, with the increase in government environmental protection spending, enterprises will reduce or even cancel the funds originally intended to be invested in environmental protection. When government spending on environmental protection increases to a certain extent, the subsidies received by enterprises that make environmental protection investment from the government will also increase. Moreover, government spending on environmental protection will have a strong guiding effect on social investment, leading to a change in the direction of social capital investment. The cost of environmental protection investment by enterprises will gradually decline, and the enthusiasm for environmental protection investment will increase significantly.

The regression coefficient of the infrastructure quadratic term is negative and passes the significance test at the $1 \%$ level, indicating that there is a significant inverted U-shaped relationship between environmental infrastructure and corporate environmental protection investment. The improvement in the level of green infrastructure will reduce the cost of corporate environmental protection investment, which will play a role in promoting corporate environmental protection investment behavior. Excessive investment in green infrastructure will crowd out other types of government investment and will have a dampening effect on corporate environmental protection behavior from a long-term perspective.

The regression coefficient of the quadratic term of environmental governance is significantly positive at the $1 \%$ level, indicating that there is a significant $\mathrm{U}$ shaped relationship between environmental governance and corporate environmental protection investment. Under loose government environmental control policies and enforcement, the amount of environmental protection investment required by enterprises is higher than environmental taxes and environmental fines, and enterprises prefer to pay relatively less environmental taxes and environmental fines to reduce the amount of environmental protection investment, therefore, the increase in the intensity of government environmental control plays a negative role in the environmental protection investment behavior of enterprises. When environmental regulation continues to be strengthened and reaches a certain level, the cost of environmental taxes and environmental fines paid by enterprises exceeds the investment in environmental protection, then enterprises have to actively invest in environmental management and environmental protection, therefore, stricter environmental regulation plays a positive role in enterprises' environmental protection investment.

The coefficients of CSR in the regression analysis of the impact of three types of green policy on corporate environmental protection investment are all significantly positive, indicating that CSR can positively promote corporate environmental protection investment. Companies that value social responsibility Loading [MathJax]/jax/output/CommonHTML/fonts/TeX/fontdata.js tion and pollution reduction, thus increasing investment in environmental protection. Corporate

Page $10 / 20$ 
environmental protection investment is not only influenced by the external policy environment but also driven by internal corporate social responsibility. Green policy and corporate social responsibility have a joint effect on corporate environmental protection investment.

Table 3

The result of the regression of different green policy tools.

\begin{tabular}{|c|c|c|c|c|c|c|c|c|c|}
\hline & (1) & (2) & (3) & (4) & $(5)$ & (6) & (7) & (8) & (9) \\
\hline & $\begin{array}{l}\text { Green } \\
\text { investment }\end{array}$ & $\begin{array}{l}\text { Green } \\
\text { investment }\end{array}$ & $\begin{array}{l}\text { Green } \\
\text { investment }\end{array}$ & Infrastructure & Infrastructure & Infrastructure & $\begin{array}{l}\text { Environmental } \\
\text { governance }\end{array}$ & $\begin{array}{l}\text { Environmental } \\
\text { governance }\end{array}$ & $\begin{array}{l}\text { Enviro } \\
\text { goverr }\end{array}$ \\
\hline & EPI & EPI & EPI & EPI & EPI & EPI & EPI & EPI & EPI \\
\hline \multirow[t]{2}{*}{ Policy } & $-0.247651^{\star}$ & & $-0.244715^{\star}$ & $-0.214323^{\star \star}$ & & -0.212398 ** & $-0.359022^{\star \star}$ & & -0.355 \\
\hline & $(-1.760)$ & & $(-1.788)$ & $(-2.373)$ & & $(-2.410)$ & $(-2.213)$ & & $(-2.24 \xi$ \\
\hline \multirow[t]{2}{*}{ Policy ${ }^{2}$} & $1.33 e+02^{\star \star *}$ & & $1.32 \mathrm{e}+02^{\star \star \star}$ & $-17.847854^{\star \star \star}$ & & $-17.710147 * \star \star$ & $90.826220 * \star *$ & & 90.14: \\
\hline & (3.124) & & $(3.160)$ & (2.773) & & $(2.811)$ & (2.859) & & $(2.897$ \\
\hline \multirow[t]{2}{*}{ CSR } & & $0.000976^{* *}$ & $0.001911^{*}$ & & 0.000976 ** & $0.001911^{\star}$ & & $0.000976 * \star$ & 0.001 ! \\
\hline & & $(2.323)$ & $(0.602)$ & & $(2.323)$ & $(0.602)$ & & $(2.323)$ & $(0.602$ \\
\hline \multirow[t]{2}{*}{ Opportunity } & -0.000080 & 0.000117 & -0.000073 & -0.000080 & 0.000117 & -0.000073 & -0.000080 & 0.000117 & -0.000 \\
\hline & $(-0.190)$ & $(0.823)$ & $(-0.175)$ & $(-0.190)$ & $(0.823)$ & $(-0.175)$ & $(-0.190)$ & $(0.823)$ & $(-0.17 !$ \\
\hline \multirow[t]{2}{*}{ Size } & 0.000072 & -0.000093 & 0.000037 & 0.000072 & -0.000093 & 0.000037 & 0.000072 & -0.000093 & 0.0001 \\
\hline & $(0.060)$ & $(-0.265)$ & $(0.030)$ & $(0.060)$ & $(-0.265)$ & $(0.030)$ & $(0.060)$ & $(-0.265)$ & $(0.030$ \\
\hline \multirow[t]{2}{*}{ Lev } & 0.002451 & 0.000231 & 0.002366 & 0.002451 & 0.000231 & 0.002366 & 0.002451 & 0.000231 & $0.002:$ \\
\hline & $(0.894)$ & $(0.266)$ & $(0.875)$ & $(0.894)$ & $(0.266)$ & $(0.875)$ & $(0.894)$ & $(0.266)$ & (0.875 \\
\hline \multirow[t]{2}{*}{ Age } & $0.001016^{\star \star \star}$ & $0.000564^{\star *}$ & $0.001037 * \star \star$ & $0.001016 * \star \star *$ & 0.000564 ** & $0.001037 * \star \star$ & 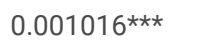 & 0.000564 ** & 0.0011 \\
\hline & (3.603) & $(2.295)$ & (3.716) & $(3.603)$ & $(2.295)$ & (3.716) & (3.603) & $(2.295)$ & (3.716 \\
\hline \multirow[t]{2}{*}{ ROA } & 0.010842 & 0.004124 & 0.009547 & 0.010842 & 0.004124 & 0.009547 & 0.010842 & 0.004124 & $0.009 !$ \\
\hline & $(1.404)$ & $(1.480)$ & (1.184) & (1.404) & $(1.480)$ & $(1.184)$ & $(1.404)$ & $(1.480)$ & (1.184 \\
\hline \multirow[t]{2}{*}{ Growth } & 0.000380 & 0.000046 & 0.000365 & 0.000380 & 0.000046 & 0.000365 & 0.000380 & 0.000046 & $0.000:$ \\
\hline & $(0.882)$ & $(0.229)$ & $(0.836)$ & $(0.882)$ & $(0.229)$ & $(0.836)$ & $(0.882)$ & $(0.229)$ & $(0.836$ \\
\hline \multirow[t]{2}{*}{ Far } & $0.007559 * \star$ & $0.002325^{\star}$ & $0.007550 * \star$ & $0.007559 * \star$ & $0.002325^{\star}$ & $0.007550 * *$ & $0.007559 * \star$ & $0.002325^{\star}$ & $0.007 !$ \\
\hline & $(2.172)$ & $(1.931)$ & $(2.142)$ & $(2.172)$ & $(1.931)$ & $(2.142)$ & $(2.172)$ & $(1.931)$ & $(2.142$ \\
\hline \multirow[t]{2}{*}{ Flow } & $-0.003463^{*}$ & -0.001274 & $-0.003572^{*}$ & $-0.003463^{*}$ & -0.001274 & $-0.003572^{\star}$ & $-0.003463^{*}$ & -0.001274 & -0.003 \\
\hline & $(-1.714)$ & $(-1.309)$ & $(-1.723)$ & $(-1.714)$ & $(-1.309)$ & $(-1.723)$ & $(-1.714)$ & $(-1.309)$ & $(-1.72 i$ \\
\hline \multirow[t]{2}{*}{ Cash } & 0.001800 & 0.000846 & 0.001870 & 0.001800 & 0.000846 & 0.001870 & 0.001800 & 0.000846 & $0.001\}$ \\
\hline & $(0.646)$ & $(0.691)$ & $(0.667)$ & $(0.646)$ & $(0.691)$ & $(0.667)$ & $(0.646)$ & $(0.691)$ & $(0.667$ \\
\hline \multirow[t]{2}{*}{ Top } & -0.000084 & -0.002117 & -0.000483 & -0.000084 & -0.002117 & -0.000483 & -0.000084 & -0.002117 & -0.000 \\
\hline & $(-0.023)$ & $(-1.330)$ & $(-0.129)$ & $(-0.023)$ & $(-1.330)$ & $(-0.129)$ & $(-0.023)$ & $(-1.330)$ & $(-0.12$ ? \\
\hline \multirow[t]{2}{*}{ _cons } & -0.024527 & -0.005087 & -0.024327 & -0.028846 & -0.005087 & -0.028611 & -0.026513 & -0.005087 & -0.026 \\
\hline & $(-0.837)$ & $(-0.615)$ & $(-0.820)$ & $(-1.016)$ & $(-0.615)$ & $(-0.995)$ & $(-0.918)$ & $(-0.615)$ & $(-0.89$ ! \\
\hline Year & Control & Control & Control & Control & Control & Control & Control & Control & Contrc \\
\hline$N$ & 522 & 878 & 515 & 522 & 878 & 515 & 522 & 878 & 515 \\
\hline $\mathrm{F}$ & 3.917 & 3.291 & 3.968 & 3.917 & 3.291 & 3.968 & 3.917 & 3.291 & 3.968 \\
\hline $\mathrm{R}^{2}$ & 0.190 & 0.149 & 0.191 & 0.190 & 0.149 & 0.191 & 0.190 & 0.149 & 0.191 \\
\hline
\end{tabular}

Note: (1) *** $p<0.01, * \star p<0.05, * p<0.1$. (2) Figures in parentheses are standard errors

\subsubsection{Regional heterogeneity analysis.}


investment. In addition, there are significant differences in policies and regulations, market competition, and cultural environments in different regions of China. Enterprises are living in different environments and fulfill their corporate social responsibility in different ways. As a result, the impact of corporate social responsibility on corporate environmental protection investment varies from region to region. For all samples, this paper divided the 30 provinces (municipalities directly under the Central Government and autonomous regions) where the heavy pollution-containing industries are located into three regions: eastern, central, and western, and used panel fixed-effects models to test and regress different regions separately to analyze regional differences in the effects of green policy and corporate social responsibility on corporate environmental protection investment. The regression results are shown in Table 4 . The regression coefficients of the squared terms of green policy in the eastern and western regions are significantly positive at the $1 \%$ level, indicating a significant and robust U-shaped relationship between green policy and corporate environmental protection investment in these two regions. The regression coefficient of the squared term of green policy in the central region is significantly negative at the $5 \%$ level, indicating an inverted U-shaped relationship between green policy in the western region and environmental protection investment of local corporates. The social responsibility fulfillment of enterprises in the western region has a significant positive impact on corporate environmental protection investment, while the performance of corporate social responsibilities in the eastern and central regions has no significant impact on environmental protection investment behavior. 
Table 4

The regression results of different regions

\begin{tabular}{|c|c|c|c|c|c|c|c|c|c|}
\hline & (1) & (2) & (3) & (4) & (5) & (6) & (7) & (8) & (9) \\
\hline & Eastern & Eastern & Eastern & Central & Central & Central & Western & Western & Western \\
\hline & EPI & EPI & EPI & $\mathrm{EPI}$ & EPI & EPI & $\mathrm{EPI}$ & $\mathrm{EPI}$ & EPI \\
\hline \multirow[t]{2}{*}{ Policy } & $0.421023^{\star \star \star}$ & & $0.414330 * \star \star$ & -0.928351 ** & & $-0.918366^{\star}$ & $2.288383^{\star \star \star}$ & & $2.315511 * \star \star$ \\
\hline & $(4.230)$ & & (4.191) & $(-2.035)$ & & $(-2.015)$ & $(5.575)$ & & (6.133) \\
\hline \multirow[t]{2}{*}{ Policy ${ }^{2}$} & $8.341189 * \star \star$ & & $8.151625^{\star \star \star}$ & $-1.19 e+02^{\star \star}$ & & $-1.18 e+02^{\star \star}$ & $52.777492^{\star \star \star}$ & & $54.093494 * \star \star$ \\
\hline & $(4.226)$ & & $(4.183)$ & $(-2.022)$ & & $(-2.001)$ & $(5.211)$ & & $(6.136)$ \\
\hline \multirow[t]{2}{*}{ CSR } & & 0.000797 & 0.000797 & & 0.000770 & 0.000770 & & $0.003022^{\star *}$ & $0.003022^{\star \star}$ \\
\hline & & $(1.552)$ & $(1.552)$ & & $(1.068)$ & $(1.068)$ & & $(1.765)$ & $(1.765)$ \\
\hline \multirow[t]{2}{*}{ Opportunity } & 0.000258 & 0.000273 & 0.000273 & 0.000154 & 0.000168 & 0.000168 & -0.000232 & -0.000302 & -0.000302 \\
\hline & $(1.360)$ & $(1.448)$ & $(1.448)$ & $(0.483)$ & $(0.524)$ & $(0.524)$ & $(-0.741)$ & $(-0.951)$ & $(-0.951)$ \\
\hline \multirow[t]{2}{*}{ Size } & -0.000170 & -0.000195 & -0.000195 & 0.000656 & 0.000588 & 0.000588 & -0.001494 & -0.001645 & -0.001645 \\
\hline & $(-0.433)$ & $(-0.498)$ & $(-0.498)$ & $(1.297)$ & $(1.172)$ & $(1.172)$ & $(-0.917)$ & $(-1.045)$ & $(-1.045)$ \\
\hline \multirow[t]{2}{*}{ Lev } & 0.001323 & 0.001276 & 0.001276 & 0.000729 & 0.000704 & 0.000704 & -0.001156 & -0.001501 & -0.001501 \\
\hline & $(1.600)$ & $(1.556)$ & $(1.556)$ & $(0.267)$ & $(0.258)$ & $(0.258)$ & $(-0.322)$ & $(-0.412)$ & $(-0.412)$ \\
\hline \multirow[t]{2}{*}{ Age } & $0.000299 * *$ & $0.000331^{\star *}$ & $0.000331^{\star *}$ & $0.014983^{\star \star}$ & $0.000365^{\star *}$ & $0.014868^{*}$ & 0.000450 & 0.000303 & 0.000303 \\
\hline & $(2.003)$ & $(2.247)$ & $(2.247)$ & $(2.033)$ & $(2.231)$ & $(2.015)$ & $(0.289)$ & $(0.205)$ & $(0.205)$ \\
\hline \multirow[t]{2}{*}{ ROA } & 0.004128 ** & $0.003539 *$ & $0.003539 *$ & -0.010803 & -0.011604 & -0.011604 & 0.009606 & 0.006769 & 0.006769 \\
\hline & $(2.017)$ & $(1.731)$ & $(1.731)$ & $(-1.184)$ & $(-1.232)$ & $(-1.232)$ & $(1.575)$ & (1.099) & (1.099) \\
\hline \multirow[t]{2}{*}{ Growth } & 0.000081 & 0.000091 & 0.000091 & 0.000033 & 0.000007 & 0.000007 & -0.000401 & -0.000289 & -0.000289 \\
\hline & $(0.257)$ & $(0.293)$ & $(0.293)$ & $(0.040)$ & $(0.008)$ & $(0.008)$ & $(-0.692)$ & $(-0.498)$ & $(-0.498)$ \\
\hline \multirow[t]{2}{*}{ Far } & $0.002349 * \star$ & $0.002355^{\star \star}$ & $0.002355^{\star \star}$ & -0.009544 & -0.009048 & -0.009048 & 0.002012 & 0.001067 & 0.001067 \\
\hline & $(2.372)$ & $(2.373)$ & $(2.373)$ & $(-1.020)$ & $(-0.979)$ & $(-0.979)$ & $(0.482)$ & $(0.258)$ & $(0.258)$ \\
\hline \multirow[t]{2}{*}{ Flow } & $-0.001937 *$ & $-0.002017 *$ & $-0.002017^{\star}$ & 0.002887 & 0.002972 & 0.002972 & -0.002131 & -0.002663 & -0.002663 \\
\hline & $(-1.775)$ & $(-1.824)$ & $(-1.824)$ & $(0.493)$ & $(0.506)$ & $(0.506)$ & $(-0.558)$ & $(-0.681)$ & $(-0.681)$ \\
\hline \multirow[t]{2}{*}{ Cash } & 0.001328 & 0.001304 & 0.001304 & -0.009479 & -0.009345 & -0.009345 & $0.005251^{\star \star}$ & $0.004965^{\star \star}$ & $0.004965^{\star \star}$ \\
\hline & $(1.145)$ & (1.139) & (1.139) & $(-0.978)$ & $(-0.962)$ & $(-0.962)$ & $(2.286)$ & (2.198) & (2.198) \\
\hline \multirow[t]{2}{*}{ Top } & -0.001581 & -0.001691 & -0.001691 & -0.009900 & -0.009845 & -0.009845 & -0.008386 & -0.009656 & -0.009656 \\
\hline & $(-0.708)$ & $(-0.762)$ & $(-0.762)$ & $(-1.402)$ & $(-1.395)$ & $(-1.395)$ & $(-0.821)$ & $(-1.040)$ & $(-1.040)$ \\
\hline \multirow[t]{2}{*}{ _cons } & 0.001857 & -0.000459 & 0.001691 & $-0.204407^{\star *}$ & -0.008087 & $-0.201891 * *$ & 0.027227 & 0.036855 & 0.032727 \\
\hline & $(0.195)$ & $(-0.047)$ & $(0.178)$ & $(-2.119)$ & $(-0.968)$ & $(-2.098)$ & $(0.904)$ & (1.299) & $(1.152)$ \\
\hline Year & Control & Control & Control & Control & Control & Control & Control & Control & Control \\
\hline $\mathrm{N}$ & 602 & 598 & 598 & 155 & 155 & 155 & 126 & 125 & 125 \\
\hline $\mathrm{F}$ & 3.508 & 3.121 & 3.121 & 1.346 & 1.382 & 1.382 & 8.820 & 14.464 & 14.464 \\
\hline $\mathrm{R}^{2}$ & 0.124 & 0.129 & 0.129 & 0.245 & 0.246 & 0.246 & 0.437 & 0.454 & 0.454 \\
\hline
\end{tabular}

\subsection{Moderating effect of market competition}

To study the moderating effect of market competition, this paper introduced the interaction term of the squared term of green policy and market competition and the interaction term of green policy and market competition into the model. The regression results of model 4 are presented in Table 5 . First, in the regression analysis of all samples, the coefficient of the interaction term between the squared term of green policy and corporate environmental protection investment is significantly positive at the $1 \%$ level, which indicates that market competition positively moderates the U-shaped relationship between green Loading [MathJax]/jax/output/CommonHTML/fonts/TeX/fontdata.js . This paper further classified green policy into three types: green investment, infrastructure, and 
environmental governance to analyze the moderating role of market competition under different green policy types. Then, as for the green investment and environmental governance, the coefficients of the interaction term of the quadratic term are both significantly positive at the $1 \%$ level, which shows that market competition strengthens the U-shaped relationship between green investment, environmental governance and corporate environmental investment each. When comes to the infrastructure green policy, the coefficient of the interaction term between the square of infrastructure and corporate environmental protection investment is significantly negative at the $1 \%$ level, which shows that market competition strengthens the inverted U-shaped relationship between infrastructure and corporate environmental protection investment. Companies in highly competitive industries are more active towards green policy issued by the government, and market competition plays a positive moderating role in the relationship between green policy and corporate environmental protection investment. Hypothesis 4 of this paper has been verified. 
Table 5

The results of moderating effect of market competition

\begin{tabular}{|c|c|c|c|c|}
\hline & (1) & (2) & (3) & (4) \\
\hline & Full-sample & Green investment & Infrastructure & Environmental governance \\
\hline & EPI & EPI & EPI & EPI \\
\hline \multirow[t]{2}{*}{ Policy } & $0.776256^{\star \star \star}$ & $-0.404377 * \star \star$ & $0.303044^{\star \star \star}$ & $-0.524440 * \star \star$ \\
\hline & $(5.262)$ & $(-2.892)$ & $(-3.318)$ & $(-3.210)$ \\
\hline \multirow[t]{2}{*}{ Policy ${ }^{2}$} & $15.680405^{\star \star \star}$ & $1.67 e+02 * \star \star$ & $-23.509699 * \star \star$ & $1.18 \mathrm{e}+02^{\star \star \star}$ \\
\hline & $(4.813)$ & $(3.787)$ & $(3.575)$ & $(3.628)$ \\
\hline \multirow[t]{2}{*}{ Policy $\times$ MC } & $-0.000225^{\star *}$ & $-0.014063^{\star *}$ & $-0.009235^{\star}$ & $-0.016521^{*}$ \\
\hline & $(-2.158)$ & $(-1.984)$ & $(-1.941)$ & $(-1.953)$ \\
\hline \multirow[t]{2}{*}{ Policy $^{2} \times \mathrm{MC}$} & $0.007616^{* *}$ & $4.365268^{\star \star}$ & $-0.661058^{*}$ & 3.261128 ** \\
\hline & $(1.216)$ & $(1.879)$ & $(1.910)$ & $(1.903)$ \\
\hline \multirow[t]{2}{*}{ CSR } & $0.000973^{\star *}$ & $0.002450 * *$ & $0.002450 * *$ & $0.002450 * *$ \\
\hline & $(2.254)$ & $(0.732)$ & $(0.732)$ & $(0.732)$ \\
\hline \multirow[t]{2}{*}{ Opportunity } & 0.000129 & -0.000141 & -0.000141 & -0.000141 \\
\hline & $(0.902)$ & $(-0.337)$ & $(-0.337)$ & $(-0.337)$ \\
\hline \multirow[t]{2}{*}{ Size } & -0.000218 & -0.000543 & -0.000543 & -0.000543 \\
\hline & $(-0.704)$ & $(-0.479)$ & $(-0.479)$ & $(-0.479)$ \\
\hline \multirow[t]{2}{*}{ Lev } & 0.000144 & 0.002259 & 0.002259 & 0.002259 \\
\hline & $(0.165)$ & $(0.853)$ & $(0.853)$ & $(0.853)$ \\
\hline \multirow[t]{2}{*}{ Age } & $0.000451^{\star \star}$ & $0.000693^{\star \star *}$ & $0.000693^{\star \star \star}$ & $0.000693^{\star * *}$ \\
\hline & $(2.065)$ & $(2.712)$ & $(2.712)$ & $(2.712)$ \\
\hline \multirow[t]{2}{*}{ ROA } & 0.004023 & 0.009412 & 0.009412 & 0.009412 \\
\hline & $(1.446)$ & (1.174) & (1.174) & (1.174) \\
\hline \multirow[t]{2}{*}{ Growth } & 0.000104 & 0.000554 & 0.000554 & 0.000554 \\
\hline & $(0.499)$ & (1.303) & (1.303) & (1.303) \\
\hline \multirow[t]{2}{*}{ Far } & $0.002243^{*}$ & $0.007008^{* *}$ & $0.007008^{\star \star}$ & $0.007008^{* *}$ \\
\hline & $(1.891)$ & $(2.058)$ & $(2.058)$ & $(2.058)$ \\
\hline \multirow[t]{2}{*}{ Flow } & -0.001411 & $-0.003814^{\star}$ & $-0.003814^{\star}$ & $-0.003814^{\star}$ \\
\hline & $(-1.414)$ & $(-1.757)$ & $(-1.757)$ & $(-1.757)$ \\
\hline \multirow[t]{2}{*}{ Cash } & 0.000926 & 0.002308 & 0.002308 & 0.002308 \\
\hline & $(0.780)$ & $(0.819)$ & $(0.819)$ & $(0.819)$ \\
\hline \multirow[t]{2}{*}{ Top } & -0.001445 & 0.000661 & 0.000661 & 0.000661 \\
\hline & $(-1.038)$ & $(0.196)$ & $(0.196)$ & $(0.196)$ \\
\hline \multirow[t]{2}{*}{ MC } & -0.000013 & -0.000062 & $-0.000230^{\star}$ & -0.000139 \\
\hline & $(-0.577)$ & $(-1.093)$ & $(-1.769)$ & $(-1.596)$ \\
\hline \multirow[t]{2}{*}{ _cons } & 0.003729 & -0.005646 & -0.011467 & -0.008324 \\
\hline & $(0.530)$ & $(-0.214)$ & $(-0.451)$ & $(-0.321)$ \\
\hline Year & Control & Control & Control & Control \\
\hline $\mathrm{N}$ & 878 & 515 & 515 & 515 \\
\hline $\mathrm{F}$ & 2.730 & 3.283 & 3.283 & 3.283 \\
\hline $\mathrm{R}^{2}$ & 0.159 & 0.215 & 0.215 & 0.215 \\
\hline
\end{tabular}




\subsection{Robust test}

First, this paper transformed the core variables EPI and CSR by the natural logarithm of the amount of corporate environmental protection investment and the data of Rankins CSR Ratings. Secondly, this paper adopted the SYS-GMM method to conduct the robust analysis. The results of the robust test are shown in Table 6 . The results of the robust test show that hypothesis 1 , hypothesis 2 , and hypothesis 3 of this paper pass the statistical verification, which confirm the validity of the previous estimation approach. 
Table 6

The results of robust text

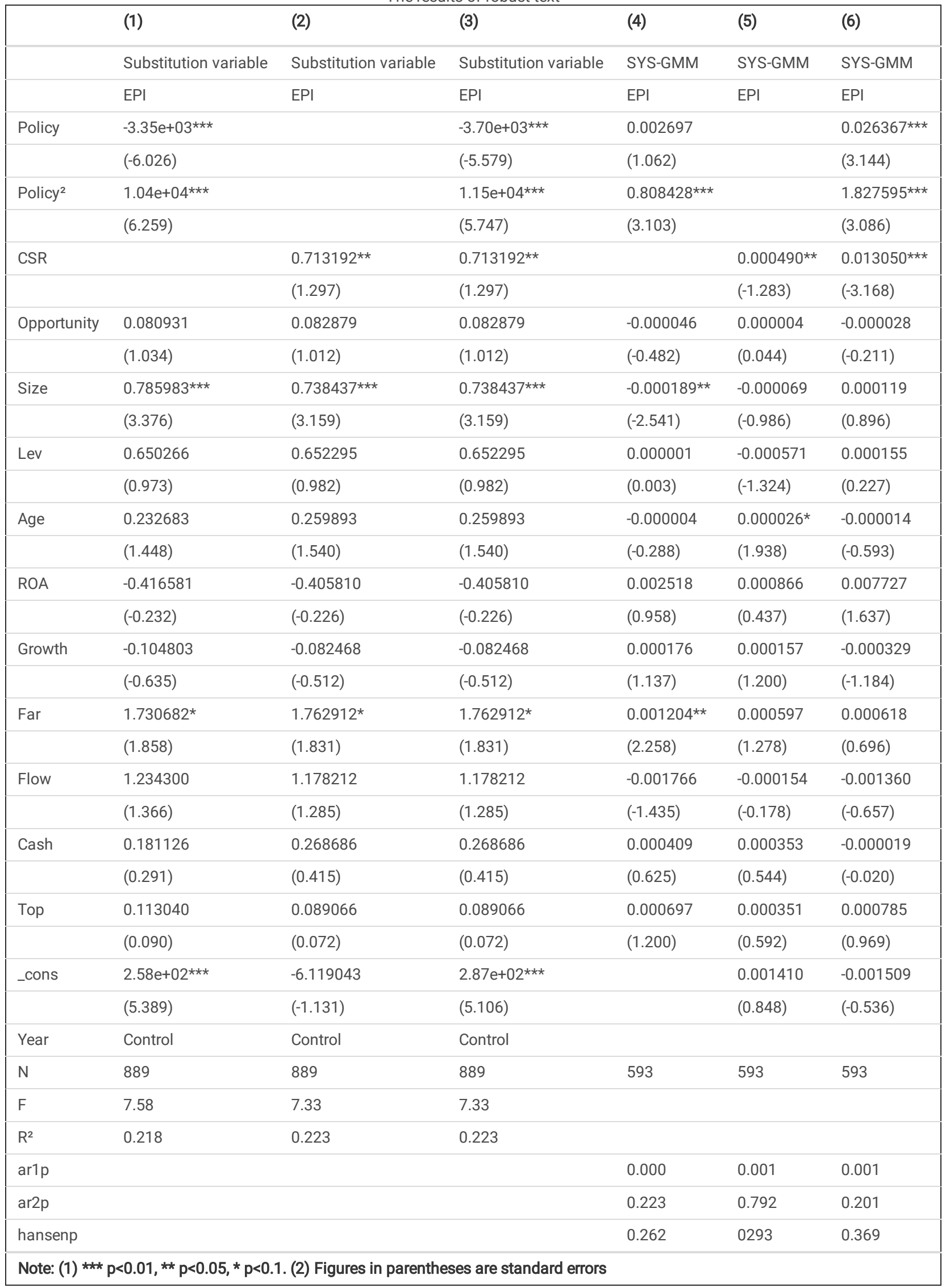

\section{Conclusions And Policy Recommendations}

Based on the data of Chinese listed companies in heavy pollution industry from 2013 to 2019, this paper combined with market competition, empirically Loading [MathJax]/jax/output/CommonHTML/fonts/TeX/fontdata.js te social responsibility, and corporate environmental protection investment. The empirical results 
show that: (1) There is a significant "U"-shaped relationship between the level of green policy and corporate environmental protection investment. When making investment decisions, companies will simultaneously measure the relative scale of environmental protection investment income and environmental protection investment costs. (2) Corporate social responsibility and corporate environmental protection investment are positively correlated, based on the fact that environmental protection investment will create economic, social, and environmental benefits for enterprises, enterprises will tend to increase their investment in environmental protection when fulfilling their social responsibility;(3)Green policy and corporate social responsibility have a joint effect on corporate environmental protection investment. The lenient green policy will not increase the scale of corporate investment in environmental protection, but when the green policy is improved to a certain extent, it will work together with corporate social responsibility to increase the scale of corporate environmental protection investment. (4)Different types of green policy tools have different effects on corporate environmental protection investment. There is a U-shaped relationship between the scale of corporate environmental protection investment and corporate environmental protection investment, and between the scale of corporate environmental protection investment and corporate environmental protection investment, and there is an inverted U-shaped relationship between the level of green infrastructure and the scale of corporate environmental protection investment. (5) From a regional perspective, there is a significant U-shaped relationship between the green policy of the eastern and western regions and the environmental protection investment of local enterprises. The green policy in the western region has an inverted U-shaped relationship with the environmental protection investment of local enterprises. (6) Market competition can positively moderate the relationship between green policy and corporate environmental protection investment

Based on the research findings, this paper makes the following recommendations: Firstly, the government should accelerate the innovation of green policy tools and enhance the feasibility and applicability of green policy. In addition, the government should fully consider China's property rights, regional differences, and industry differences, and formulate differentiated green policy tools based on the different stages of China's environmental governance. Through the improvement of green policy tools, the government, the market, and the public can actively play a synergistic role and promote the optimal combination of three green policy tools, green investment, infrastructure, and environmental governance. Secondly, enterprises should take the initiative to benchmark high-quality development, strengthen social responsibility education for organization members, and motivate all employees to invest in socially responsible management strategies. Consciously fulfilling their environmental obligations and actively investing in the environment, enterprises should promote technological innovation in environmental management and pollution control, so that they will continuously improve their environmental management performance and achieve sustainable development in business and environmental protection. Thirdly, the government should further regulate market access, strengthen value identification mechanisms, and promote the construction of a greener and more orderly market competition environment. Through value leadership, the government should guide enterprises to consciously incorporate environmental responsibility into their long-term strategies.

\section{Declarations}

Ethics approval and consent to participate: Not applicable

Consent for publication: Not applicable

Availability of data and materials: The data used to support the findings of this study are available from the corresponding author upon request.

Competing interests: The author declared that this paper no competing interests.

Funding: Not applicable

Authors' contributions: The author contributed to the manuscript and studies.

Acknowledgements: Not applicable

\section{References}

1. Baumgartner, Rupert J . Managing Corporate Sustainability and CSR: A Conceptual Framework Combining Values, Strategies and Instruments Contributing to Sustainable Development[J]. Corporate Social Responsibility \& Environmental Management, 2013, 21(5):258-271. https://doi.org/10.1002/csr.1336

2. Chaton C, Guillerminet M L. Competition and environmental policies in an electricity sector[J]. Energy Economics, 2013, 36(Mar.):215-228. https://doi.org/10.1016/j.eneco.2012.08.014

3. Despeisse M, Ball P D, Evans S, et al. Industrial ecology at factory level-a conceptual model[J]. Journal of Cleaner Production, $2012,31$. https://doi.org/10.1016/j.jclepro.2012.02.027

4. Farzin Y. H., Kort P. M. Pollution Abatement Investment with Environmental Regulation is Uncertain[J]. Journal of Public Economic Theory,2000,2:183212. https://doi.org/10.1111/1097-3923.00036

5. Fu Yuanhai, Wang Xiaotong. Research on the influence of imitation and competition effects on the optimization of manufacturing structure[J]. Auditing and Economic Research, 2018, 33(04): 105-115.

6. Fuentes-Blasco, M.; Moliner-V elazquez, B.; Servera-Frances, D.; Gil-Saura, I. Role of marketing and technological innovation on store equity, satisfaction and word-of-mouth in retailing.J. Prod. Brand Manag.2017,26, 650-666. https://doi.org/10.1108/JPBM-07-2016-1279

7. Gray W. B., Shadhegian R. J. Environmental Regulation Investment Timing and Technology Choice[J]. The Journal of Industrial Economic,1998,46:235256. https://doi.org/10.1111/1467-6451.00070

8. Gyves S, O'Higgins E. Corporate social responsibility: An avenue for sustainable benefit for society and the firm? [J]. Society and Business Review, 2008, Loading [MathJax]/jax/output/CommonHTML/fonts/TeX/fontdata.js 907297 
9. Hu Lixin, Liu Danzhou. Research on the Impact of Industrial Policy on Enterprise Environmental protection investment[J]. Small and Medium-sized Enterprise Management and Technology (First issue),2021(03):68-70.

10. Huang Honglin.Analysis of the impact of environmental policies on corporate environmental protection investment based on different theories[J]. National Circulation Economy, 2020(20):51-52.

11. Huang Weina, Yuan Tianrong.Substantial transformation and upgrading or strategic policy arbitrage--The impact of green industrial policy on green mergers and acquisitions of industrial enterprises[J].Journal of Shanxi University of Finance and Economics, 2021,43(03):56-67.

12. Jiang Yufeng, Tian Hong. The impact of corporate environmental responsibility and corporate environmental ethics on competitive advantage under the role of green innovation intermediary [J]. Journal of Management, 2014 (8): 781-788.

13. Kraus S, Rehman S U, Phillips F.Corporate social responsibility and environmental performance: The mediating role of environmental strategy and green innovation[J]. Technological Forecasting and Social Change, 2020, 160. https://doi.org/10.1016/j.techfore.2020.120262

14. Lao Kefu. Research on the impact mechanism of consumer innovation on green consumption behavior[J]. Nankai Management Review, 2013, 16(04): 106-113+132.

15. Leiter A M, Parolini A, Winner H. Environmental Regulation and Investment: Evidence from European Industry Data.Ecological Economic,2011,70(4):759770. https://doi.org/10.1016/j.ecolecon.2010.11.013

16. Li Cai and Chaohua He. Corporate Environmental Responsibility and Equity Prices[J]. Journal of Business Ethics, 2014, $125(4): 617-635$.

17. Li Ling, Tao Feng. The Choice of Optimal Environmental Regulation Intensity in China's Manufacturing Industry--Based on the Perspective of Green Total Factor Productivity. China Industrial Economics, 2012(05):70-82.

18. Li Qiang, Tian Shuangshuang. Can environmental regulations promote corporate environmental protection investment? --Also on the impact of market competition[J]. Journal of Beijing Institute of Technology (Social Science Edition), 2016, 18(04): 1-8.

19. Li Sihai, Li Xiaolong, Song Xianzhong. The nature of property rights, market competition and corporate social responsibility behaviors: An analysis based on the perspective of political rent-seeking[J]. China Population, Resources and Environment, 2015, 25(01): 162-169.

20. Li Xiaoxi. China Green Development Index Report[M]. Beijing: Beijing Normal University Press, 2013-2019.

21. Li Yongyou, Shen Kunrong. The emission reduction effect of China's pollution control policies: an empirical analysis based on inter-provincial industrial pollution data [J]. Management World, 2008(07): 7-17.

22. Liu Jihan, Wang Jianqiong. Corporate Social Responsibility and Capital Constraints: Evidence from Chinese Listed Companies[J].Management Review, 2012,24(11):151-157.

23. Luken R, Rompaey F V. Drivers for and barriers to environmentally sound technology adoption by manufacturing plants in nine developing countries[J]. Journal of Cleaner Production, 2008, 16(1-supp-S1):S67-S77. https://doi.org/10.1016/j.jclepro.2007.10.006

24. Luo X, Homburg C. Neglected Outcomes of Customer Satisfaction[J]. Social Science Electronic Publishing. https://doi.org/10.1509/jmkg.71.2.133

25. Mark Bagnoli and Susan G. Watts. Selling to Socially Responsible Consumers: Competition and The Private Provision of Public Goods[J]. Journal of Economics \& Management Strategy, 2003, 12(3): 419-445. https://doi.org/10.1111/j.1430-9134.2003.00419.x

26. Murovec N, Erker R S, Prodan I. Determinants of environmental protection investments: testing the structural model[J]. Journal of Cleaner Production, 2012, 37:265-277. https://doi.org/10.1016/j.jclepro.2012.07.024

27. Pagell M, Wiengarten F, Fynes B. Institutional effects and the decision to make environmental protection investments[J]. International Journal of Production Research, 2013, 51(2): 427-446. https://doi.org/10.1080/00207543.2011.651539

28. Porter M E.America's Green Strategy. Scientific American, 1991, 264(4): 168-171. https://doi.org/10.1038/scientificamerican0491-168

29. Porter M E and Linde C. Toward a New: Conception of the Environment-Competitiveness Relationship.Journal of Economic Perspectives, 1995, 9(4): 97118. https://doi.org/10.1257/jep.9.4.97

30. Ren Guangqian. Research on Corporate Environmental protection investment Behavior Based on Corporate Governance Perspective[J]. Journal of Zhengzhou University (Philosophy and Social Science Edition),2017,50(03):66-71+159.

31. Sanja Pekovic and Sebastian Vogt, 2021. The fit between corporate social responsibility and corporate governance: the impact on a firm's financial performance, Review of Managerial Science, Springer, vol. 15(4), pages 1095-1125, May. https://doi.org/10.1007/s11846-020-00389-x

32. Shen Hongbo, Xie Yue, Chen Zhengrong. Enterprise's environmental protection, social responsibility, and its market effect--A case study based on the environmental pollution incident of Zijin Mining[J]. China Industrial Economics, 2012(01):141- 151.

33. Sun Jian, Li Chongguang, Cheng Guoqiang. Research on the relationship between corporate environmental orientation, environmental protection strategy and performance [J]. Journal of Management, 2012 (6): 927-935.

34. Tang Guoping, Li Longhui, Wu Dejun. Environmental regulation, industry attributes, and corporate environmental protection investment[J]. Accounting Research, 2013(06): 83-89+96.

35. Tian J F, Pan C, Xue R, et al. Corporate innovation and environmental protection investment: The moderating role of institutional environment[J]. Advances in Climate Change Research, 2020. https://doi.org/10.1016/j.accre.2020.05.003

36. Yi Zhihong, Jiang Fuxiu, Qin Yihu. Product market competition, corporate governance and information disclosure quality [J]. Management World, 2010 (01): 133-141+161+188.

37. Yuan Yijun, Geng Dianhe. Environmental policy transmission mechanism and the development of China's environmental protection industry--Based on the game research between government, pollutant emission companies and environmental protection companies[J]. China Industrial Economics, 2010(10): 65-74

Loading [MathJax]/jax/output/CommonHTML/fonts/TeX/fontdata.js 
38. Zhang Zhaoguo, Liu Xiaoxia, Zhang Qing. Corporate Social Responsibility and Financial Management Reform--Research Based on Stakeholder Theory[J]. Accounting Research, 2009(03): 54-59+95.

39. Zhou Fangzhao,Jin Yuanpei,He Zhifang.The impact of corporate social responsibility on company performance and risk: Evidence from Chinese A-share listed companies[J].Technology and Economics,2020,39(08):119-129.

\section{Figures}

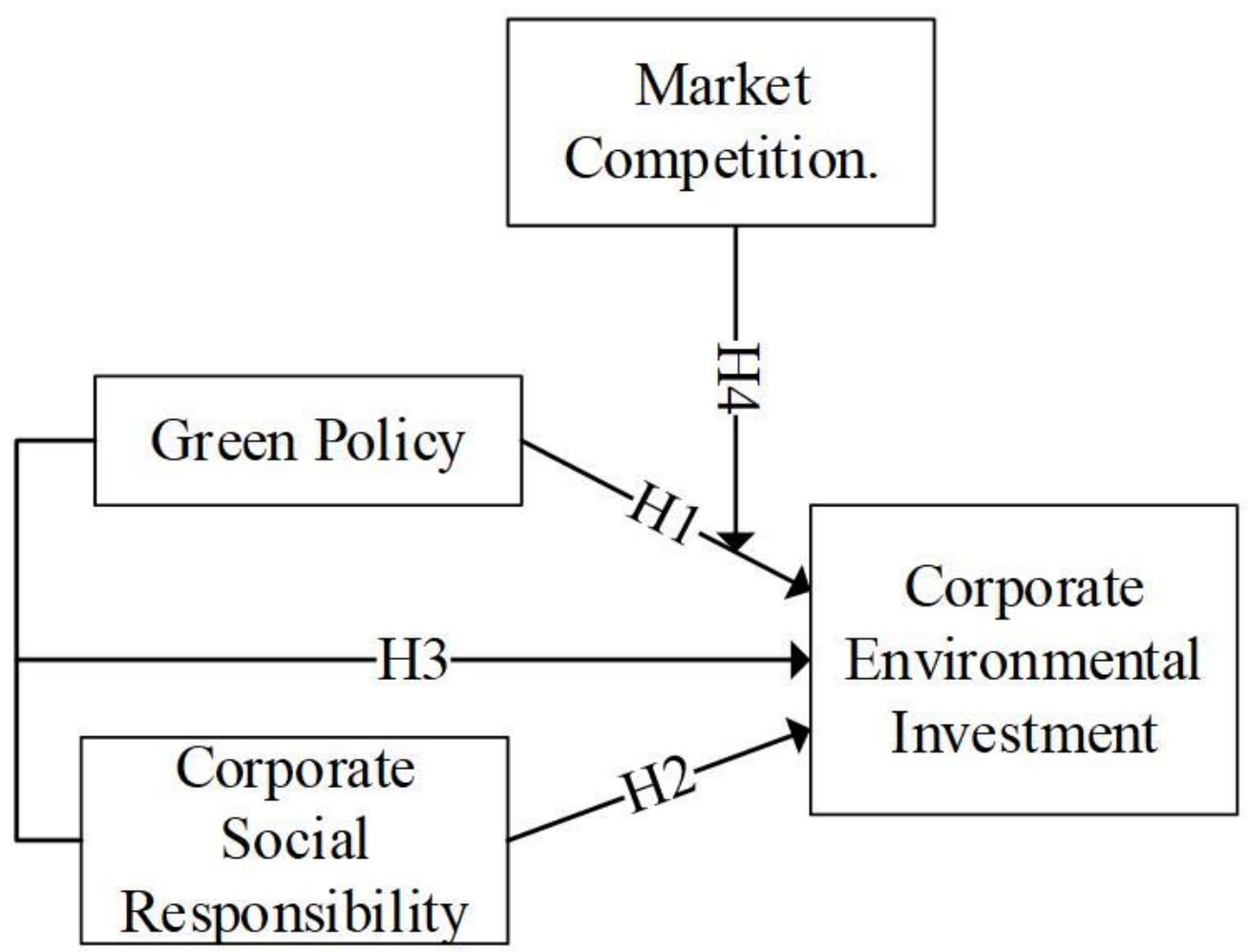

Figure 1

Hypothesized conceptual model 